\title{
Spatial and temporal dynamics of functional groups of phytoplankton in a tropical shallow lake
}

\author{
Dinâmica espaço-temporal dos grupos funcionais do fitoplâncton em lago raso tropical
}

\author{
Núbia da Silva ${ }^{1}$, João Paulo de Oliveira Santos², Danielle Lima de Oliveira², \\ Joseilson dos Santos Silva², Kelly Dayane Pereira da Silva², Ênio Wocyli Dantas ${ }^{3}$ \\ and Luciana Gomes Barbosa ${ }^{2 *}$
}

\begin{abstract}
${ }^{1}$ Núcleo de Pesquisas em Limnologia - NULIBA, Programa de Pós-graduação em Biodiversidade, Centro de Ciências Agrárias, Universidade Federal da Paraíba - UFPB, Campus II, Rodovia PB-079, CEP 58397-000, Areia, PB, Brasil

${ }^{2}$ Núcleo de Pesquisas em Limnologia - NULIBA, Centro de Ciências Agrárias, Universidade Federal da Paraíba - UFPB, Campus II, Rodovia PB-079, CEP 58397-000, Areia, PB, Brasil

${ }^{3}$ Centro de Ciências Biológicas e Sociais Aplicadas, Universidade Estadual da Paraíba - UFPB, Campus V, Rua Baraúnas, 351, Bairro Universitário, CEP 58429-500, Campina Grande, PB, Brasil

*e-mail: lgomesbarbosa@gmail.com
\end{abstract}

Cite as: Silva, N. et al. Spatial and temporal dynamics of functional groups of phytoplankton in a tropical shallow lake. Acta Limnologica Brasiliensia, 2018, vol. 30, e102.

Abstract: Aim: To evaluate the structure and dynamics of functional phytoplankton groups (FGs) over a macrophyte cover gradient and their relations with environmental variable in small, shallow clear-water lake. Methods: Physical, chemical and phytoplankton analyses were made between August 2014 and June 2015 at three points on the Santa Lucia lake (Paraiba, Brazil). Tukey and Wilcoxon tests were applied to the data followed by CCA and Anova. Results: The submerged macrophyte cover and phytoplankton biomass presented high spatial and temporal uniformity. The increase in rainfall induced small variations in functional groups, promoting increase the $\mathrm{N}$ group and reduction of the SN. Conclusion: The homogeneity in the composition and structure functional groups along macrophyte cover confirm the tendency that in small and shallow lakes communities of limnetic and shoreline zones tend to be similar.

Keywords: environmental variables; homogeneity; macrophytes; phytoplankton; shallow lakes.

Resumo: Objetivo: Avaliar a estrutura e dinâmica de grupos funcionais do fitoplâncton (GFs) ao longo de um gradiente de cobertura de macrófitas e suas relaçôes com as variáveis ambientais em lago pequeno e raso de águas claras. Métodos: Análises de variáveis físicas, químicas e da comunidade fitoplanctônica foram realizadas entre agosto 2014 a junho 2015, em três pontos distribuídos ao longo lago Santa Lúcia (Paraíba-Brasil). Testes de Tukey, Wilcoxon, seguido da CCA e Anova foram realizados. Resultados: A cobertura de macrofitas submersas e a biomassa fitoplanctônica apresentaram distribuição espaço-temporal uniforme. $\mathrm{O}$ aumento da precipitaçáo pluviométrica promoveu aumento da participação do grupo $\mathrm{N}$ e reduçáo do grupo $\mathrm{SN}$, provavelmente associados a alteraçóes na estabilidade da coluna d'água. Conclusáo: A uniformidade na composição e estrutura dos grupos funcionais ao longo da cobertura de macrófitas confirmam a tendência de que em lagos pequenos e rasos as comunidades de zonas limnéticas e litorâneas tendem a ser semelhantes.

Palavras-chave: variáveis ambientais; homogeneidade; macrófitas; fitoplâncton; lagos rasos. 


\section{Introduction}

The capacity to store and maintain water internally, susceptibility to any anthropic or even natural factors and vulnerability to seasonal events are characteristics of shallow lakes subject to abrupt changes in the quality of the water. Shifting in shallow lakes may be due to different mechanisms, such as a drastic perturbation on the system, or a stepwise change in some external condition (Scheffer \& Jeppesen, 2007).

The mechanisms stabilizing clear-water conditions are still misunderstood, however, the submersed macrophytes is supposed important mechanisms to the stabilization of sediments (Hilt, 2015) and have unfavourable effect on phytoplankton biomass through various mechanisms such as the provision of refuge from predation and high nutrient absorption (Scheffer et al., 1993).

Studies have reported that submerged macrophytes play a key role in the clear-water state of shallow lakes (Hilt, 2015; Sanchéz et al., 2015), performing as regulatory agents, highly sensitive to any changes and enhancing stability on the cascade effect. The submerged vegetation increases water transparency and, consequently, the local water quality (Hilt et al., 2010), by reducing the re-suspension of sediment nutrients. Besides, it produces allelopathic compounds that inhibit phytoplankton growth (Hilt \& Gross, 2008).

Considering the wide variety of phytoplankton species and their functional role, many studies have adopted a functional approach in order to understand changes in aquatic ecosystems based on morpho-physiological aspects and abiotic variables (Fonseca \& Bicudo, 2011; Crossetti et al., 2013). Those approaches have indicated possible patterns of co-occurrence of species that act as environmental predictors in relation to changes in the equilibrium state (Reynolds et al., 2002; Padisák et al., 2009).

In this context, this study aimed to evaluate the structure and dynamics of functional groups of the phytoplankton along a gradient of macrophyte cover and their relations with the environmental variables in a small, shallow, clear-water lake. The mainly question of this study was: Are there any differences in the composition or structure of functional groups (FGs) along the macrophyte cover?

\section{Material and Methods}

\subsection{Study area}

The Basin of the Mamanguape River is in the extreme eastern of the Paraiba state (6 $\left.36^{\prime} 49^{\prime \prime}-7^{\circ} 11^{\prime} 08^{\prime \prime} \mathrm{S} ; 34^{\circ} 54^{\prime} 42^{\prime \prime}-35^{\circ} 57^{\prime} 51^{\prime \prime} \mathrm{W}\right)$.
The climate is tropical, with temperatures ranging from 28 to $35^{\circ} \mathrm{C}$ (Alvares et al., 2013).

The Santa Lucia lake $\left(06^{\circ} 50^{\prime} 14.2\right.$ ” S, $35^{\circ} 19^{\prime} 51.4$ " W), has $444 \mathrm{~m}$ long by $128 \mathrm{~m}$ in width and extensive formations of submerged macrophytes (Nitella cernua A. Braun). The lake is designed for multiple uses, including irrigation, fishing and recreation.

\subsection{Sampling}

Samples were collected between August 2014 and July 2015 (monthly frequency) from three sampling sites located at the lake (Figure 1). Rainfall data were provided by the Executive Water Management Agency of the State of Paraiba (AESA).

\subsection{Limnological parameters}

Water temperature, dissolved oxygen, electric conductivity and $\mathrm{pH}$ were measured 'in situ' with a multiparameter probe. Water samples were collected from the sub-surface of the lake. Total phosphorus and orthophosphate were assessed using methodology described by APHA (2005).

Transparency of the water was estimated with a Secchi disk (Cole, 1994). Euphotic zone (Zeu) was calculated as 2.7 times the Secchi depth (Cole, 1994).

The euphotic zone (Zeu):mixing zone (Zmix) ratio was used as an index for light availability in the mixing zone (Jensen et al., 1994). Due to isothermal profile and shalllower depth, the mixture zone ( $\mathrm{Zmix}$ ) was considered as the equivalent to maximum zone ( $\mathrm{Zmax}$ ). The coefficient of vertical attenuation of the light $(\mathrm{k})$ was calculated by the expression $\mathrm{k}=1.7 \times \mathrm{Z}_{\mathrm{DS}}{ }^{-1}$ (Poole \& Atkins, 1929).

\subsection{Submerged macrophyte cover}

The cover of each macrophyte species was estimated visually as a percentage within a square meter area. Their abundance was estimated as a percentage of the volume of infestation (PVI) under the water (Canfield Junior et al., 1984).

\subsection{Phytoplankton}

Quantitative analysis of phytoplankton was performed according to the method described by Utermöhl (1958) by using samples fixed with aqueous acetic Lugol (1\%). A minimum of 100 individuals of the most frequent species were counted (Lund et al., 1958), and density was calculated according to the method described by Ros (1979).

Biovolume $\left(\mathrm{mm}^{3} \mathrm{~L}^{-1}\right)$ was estimated using geometric formulas (Sun \& Liu, 2003; 


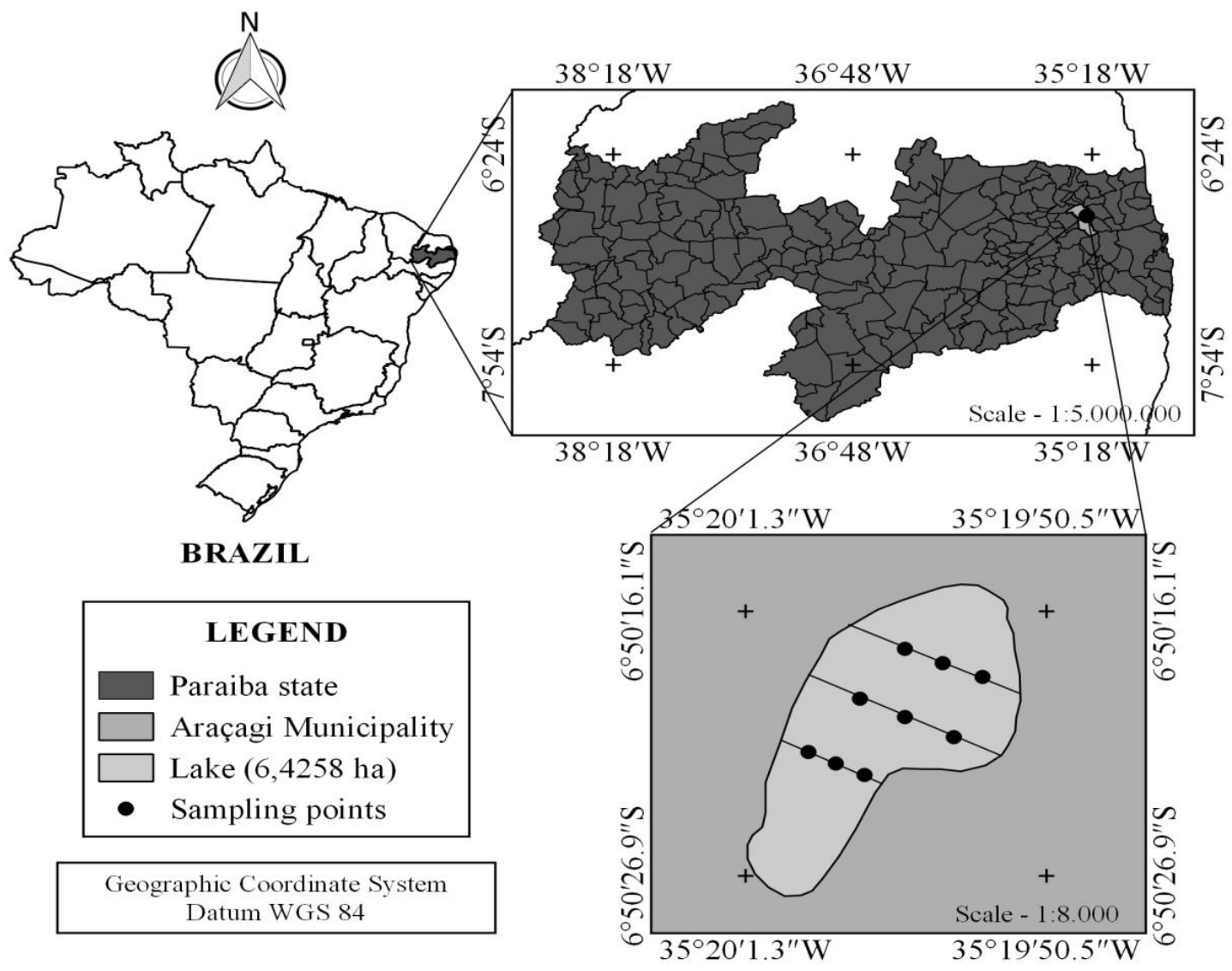

Figure 1. Location of the Santa Lucia Lake in the Paraiba state (Brazil) and the respective transects.

Hillebrand et al., 1999) with the mean values of the measurements of 20-30 individuals expressed in units of wet weight, where $1 \mathrm{~mm}^{3} \mathrm{~L}^{-1}=1 \mathrm{mg} \mathrm{L}^{-1}$ (Wetzel \& Likens, 2000).

\subsection{Data analysis}

The phytoplankton species were classified according to their relative frequencies of occurrence, which is defined as the number of sample units in which the species was observed as a percentage of the total number of sample units (Matteucci \& Colma, 1982).

The Tukey test, using a probability of value of 5\%, was applied to identify whether there were any spatial-temporal differences in the limnological variables and submerged macrophytes. Tests for significant differences of total phytoplankton biomass along the transects were performed using the Wilcoxon test. Canonical correspondence analysis (CCA) was used to assess the relationships between species of phytoplankton species and environmental variables. The CCA followed by Anova to verify the relations between the abiotic variable and the functional groups. The analyses were performed through R 3.2.2.

\section{Results}

The air temperature ranged from $27.9^{\circ} \mathrm{C}$ (September/2016) to $34.6{ }^{\circ} \mathrm{C}$ (January/2017) (Figure 2). The rainfall ranged from $26.5 \mathrm{~mm}$ (February) to $271.4 \mathrm{~mm}$ (March).

The analysis of the selected abiotic variables showed that the Santa Lúcia lake has no limitation about light with Zeu: $\mathrm{Zmix}>1$, the $\mathrm{pH}$ remained alkaline (>7) and total phosphorus values were generally low $\left(<43.5 \mu \mathrm{g} \mathrm{L}^{-1}\right)$. Water temperatures showed an isothermal profile with a complete mixture of the water column $\left(\mathrm{Z}_{\max }=\mathrm{Z}\right.$ mix $)$ and high concentrations of dissolved oxygen. In regard to temporal variation, statistically significant variations were only found for the water temperature, orthophosphate and conductivity, in the year 2015 .

The values of macrophytes infestation potential (PVI) ranging from 78.7 to $81.3 \%$, associated with submerse specie Nitella cernua A. Braun, which was 
dominant throughout the lake. Significant temporal and spatial diferences were not observed for PVI $(p \geq 0.05)$ (Table 1).

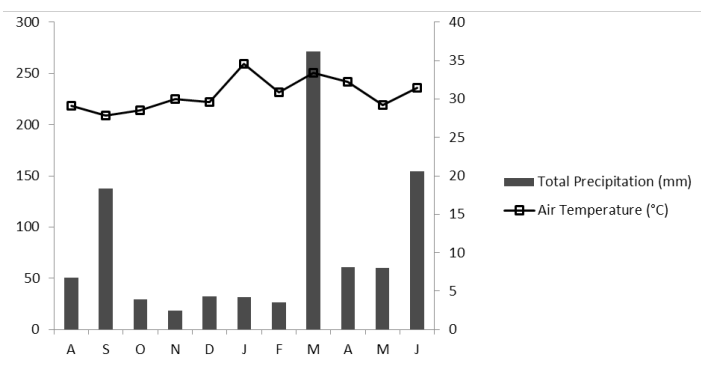

Figure 2. Total monthly rainfall $(\mathrm{mm})$ and air temperature $\left({ }^{\circ} \mathrm{C}\right)$ in the study area (Paraíba, Brazil). Legend: A (August), S (September), O (October), D (December), J (January), F (February), M (March), A (April), M (May), J (June), respectively.

\subsection{Functional groups of the phytoplankton}

The phytoplankton species were classified into eight functional groups: N, K, X1, W2, TD, SN, $\mathbf{S} 1$ and $\mathbf{P}$. Significant diferences $(P \geq 0.05)$ were not observed for total biomass.

Figure 3 shows that the $\mathbf{S} \mathbf{1}$ exhibited high values of biomass, reaching $99.9 \%$ of the total biomass during Septemper. The most frequent species were Planktonlyngbia sp., Phormidium sp. and Planktothrix agardhii. The $\mathbf{K}$ group accounted for $97 \%$ of the biomass in October and the main species encountered was Aphanocapsa annulata, whereas other species (Aphanocapsa delicatissima, Aphanocapsa sp, Synechococcus elongatus) were considered rare. In January, February and April the $\mathbf{N}$ group contributed with $73.8 \%, 81.8 \%$ and $97.4 \%$, respectively. The composition of the group was associated to desmids (Cosmarium regnelli e

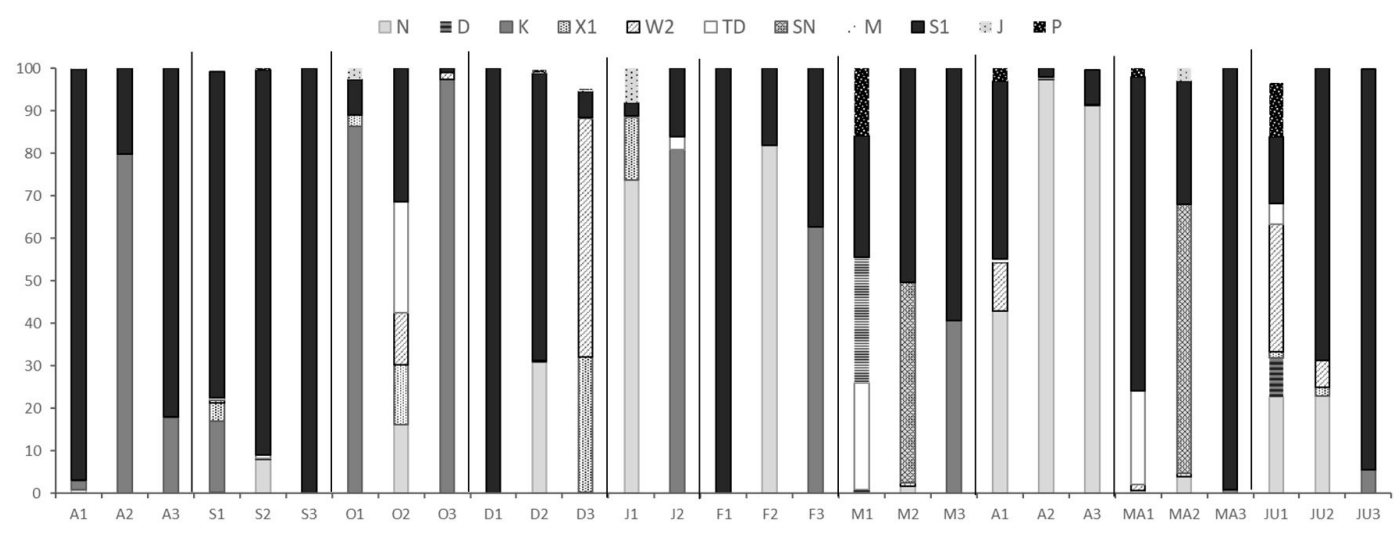

Figure 3. Contributions of those phytoplankton functional groups representing $10 \%$ or more of the total biomass in the Santa Lúcia lake from August 2014 to June 2015. Legend: A (August), S (September), O (October), D (December), J (January), F (February), M (March), A (April), MA (May), JU (June), respectively. Numbers 1,2,3: sampling points.

Table 1. Average values for the limnological variables and the macrophytes in the Santa Lúcia Lake (Paraiba, Brazil).

\begin{tabular}{|c|c|c|c|c|c|c|c|c|c|c|}
\hline \multirow{2}{*}{ Variables } & \multicolumn{4}{|c|}{2014} & \multicolumn{6}{|c|}{2015} \\
\hline & August & September & October & December & January & February & March & April & May & June \\
\hline Trans & $1.13^{\mathrm{a}}$ & $1.14^{\mathrm{a}}$ & $1.18 a$ & $0.82^{\mathrm{a}}$ & $1.07 a$ & $1.00 \mathrm{a}$ & $1.16^{a}$ & $1.16^{a}$ & $1.00 a$ & $1.11^{a}$ \\
\hline Zeu & $3.0^{\mathrm{a}}$ & $3.0^{\mathrm{a}}$ & $3.2 \mathrm{a}$ & $2.2^{\mathrm{a}}$ & $2.9 a$ & $2.7^{a}$ & $3.1^{\mathrm{a}}$ & $3.1^{\mathrm{a}}$ & $2.7 a$ & $3.0 \mathrm{a}$ \\
\hline $\mathrm{K}$ & $1.4^{\mathrm{a}}$ & $1.4^{\mathrm{a}}$ & $1.4 a$ & $0.9 a$ & $1.5 \mathrm{a}$ & $1.7^{\mathrm{a}}$ & $1.4^{\mathrm{a}}$ & $1.4^{\mathrm{a}}$ & $1.7 a$ & $1.5^{\mathrm{a}}$ \\
\hline Twater & $29.2^{\mathrm{a}}$ & $27.8^{\mathrm{a}}$ & $28.9 a$ & $19.6^{\mathrm{a}}$ & $28.6 b$ & $32.9 a$ & $30.4 a b$ & $32.1^{a}$ & $31.0 \mathrm{ab}$ & $28.7 b$ \\
\hline $\mathrm{pH}$ & $7.5^{\mathrm{a}}$ & $7.5^{\mathrm{a}}$ & $7.7 a$ & $5.3^{\mathrm{a}}$ & $7.9 a$ & $8.0^{\mathrm{a}}$ & $8.3^{\mathrm{a}}$ & $8.7^{a}$ & $8.5 a$ & $7.6^{\mathrm{a}}$ \\
\hline PT water & $40.1^{a}$ & $40.0^{\mathrm{a}}$ & $32.8 a$ & $16.2 a$ & $19.4 a$ & $20.1 a$ & $21.8^{\mathrm{a}}$ & $16.8^{\mathrm{a}}$ & $15.2 a$ & $15.7^{\mathrm{a}}$ \\
\hline P-orto & $21.5^{\mathrm{a}}$ & $22.0^{\mathrm{a}}$ & $21.2 a$ & $10.8 a$ & 11.9ab & $18.7 a$ & 14.8ab & $11.5 \mathrm{ab}$ & $7.5 b$ & $12.0 \mathrm{ab}$ \\
\hline Cond & - & - & - & - & $166.0 a$ & $163.6 a$ & $122.0 \mathrm{~b}$ & $131.0 \mathrm{~b}$ & $147.3 b$ & $105.6 \mathrm{c}$ \\
\hline OD & $7.6^{\mathrm{a}}$ & $5.5^{\mathrm{a}}$ & $8.9 a$ & $7.5 a$ & $5.9 a$ & $9.9^{\mathrm{a}}$ & $7.4^{a}$ & $13.8^{\mathrm{a}}$ & $13.9 a$ & $3.2^{\mathrm{a}}$ \\
\hline PVI & - & $75.3^{\mathrm{a}}$ & $76.1 a$ & $81.4 a$ & $81.1 a$ & $81.7 a$ & $82.3^{a}$ & $82.5^{\mathrm{a}}$ & $84.0 a$ & $81.3^{\mathrm{a}}$ \\
\hline
\end{tabular}

Averages followed by the same letter in the line do not differ from one another according to the Tukey test at 5\% probability. Trans = water transparency; Zeu = Euphotic zone; $\mathrm{pH}$, Twater $=$ water temperature; $\mathrm{PT}$ water $=$ Total phosphorus; PVI = macrophyte infestation percentage; $\mathrm{P}$-orto = dissolved phosphorus; Cond $=$ Conductivity; $\mathrm{K}=$ light attenuation coefficient; $\mathrm{OD}=$ Dissolved oxygen. 
Staurastrum taylori) and diatoms (Synedra sp. and Pennales sp.), most abundant in the central region of the lake.

The other groups, $\mathbf{P}, \mathbf{W} \mathbf{2}, \mathbf{S N}, \mathbf{T D}$ and $\mathbf{X} \mathbf{1}$, were less representative than the two most dominant groups (Figure 3 ).

To explain the eight functional groups, seven variables were selected and the Canonic Correspondence Analysis (CCA) explained $76.6 \%$ of the variability of the data obtained for the first two axes in which water temperature, orthophosphate, total phosphorus and $\mathrm{pH}$ were the variables with greatest influence on the functional group dynamics. The most important groups in the ordination of axis 1 were total phosphate and orthophosphate which influenced functional groups $\mathbf{X 1}, \mathbf{S} \mathbf{1}$ and $\mathbf{K}$, largely associated to the shoreline zones of the lake (Table 2). As regards axis 2 the most important variable in determining ordination were water temperature and $\mathrm{pH}$ and the related functional groups $\mathbf{N}, \mathbf{S N}$ and $\mathbf{T D}$ were also associated to sample units taken from the zone near the shore (Figure 4).

\section{Discussion}

The presence of the macrophytes is highly relevant insofar as they promote an increase in spatial heterogeneity (Costa \& Dantas, 2011;

Table 2. Summary of the Canonic Correspondence Analysis showing correlation coefficients among the phytoplankton functional groups and the environmental variables of the Santa Lucia Lake for the period August 2014 to June 2015.

\begin{tabular}{ccccc}
\hline Variables & CCA 1 & CCA 2 & $\mathbf{r}^{2}$ & \multicolumn{1}{c}{} \\
\hline pH & -0.98861 & -0.15052 & 0.2111 & 0.053 \\
Twater & -0.99803 & 0.06282 & 0.2860 & $0.017^{*}$ \\
Pt water & 0.97277 & -0.23179 & 0.2044 & 0.071 \\
P.orto & 0.97699 & 0.21329 & 0.2368 & $0.042^{*}$ \\
Zmix & -0.99656 & -0.08290 & 0.0395 & 0.596 \\
Zeu_Zmix & 0.91991 & 0.39212 & 0.0778 & 0.359 \\
Cond & -0.95199 & 0.30612 & 0.1669 & 0.114 \\
Explained variation (\%) & 45.7 & 30.9 & - & - \\
\hline
\end{tabular}

${ }^{*}$ Level of significance.

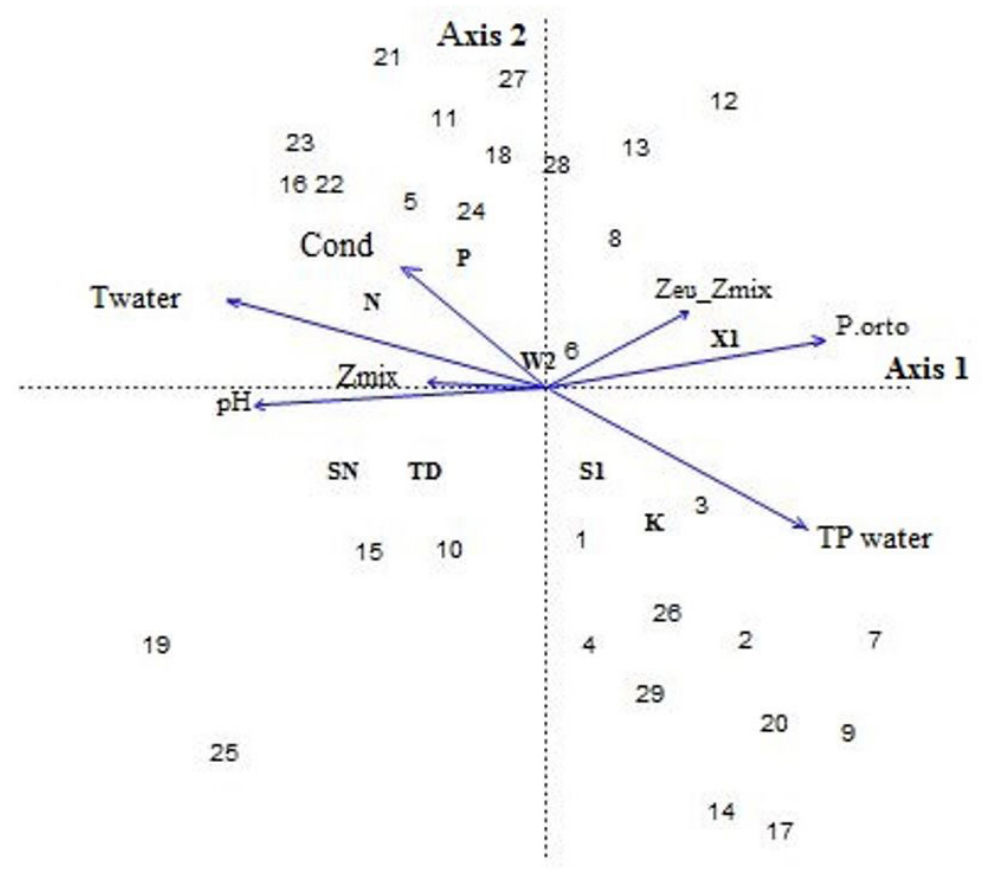

Figure 4. Canonic Correspondence Analysis (CCA) of the sample units taken from the Santa Lúcia lake generated by seven abiotic variables and the descriptive functional groups of the phytoplankton community. The numbers indicate the months and sampling points. Aug (1-3), Set (4- 6), Out (7-9), Dec (10-12), Jan (13-14), Feb (15-17), Mar (18-20), Apr (21-23), May (24-26), Jun (27-29). The limnological variables: Twater = water temperature, Cond = Conductivity, $\mathrm{pH}$, Zeu:Zmix, P.orto = orthophosphate, PTwater = total phosphorus, $\mathrm{K}=$ light attenuation coefficient. 
Izaguirre et al., 2012; Pinto \& O'Farrell, 2014). At the small shallow lakes, phytoplankton species from limnetic are usually similar to shoreline zones ones, commonly densely covered by macrophytes (Fonseca \& Bicudo, 2011). In this study, however, limnetic and shoreline zones composition were indistinguishable, due to the high degree of macrophytes homogeneity.

The apparent spatial homogeneity of biotic and abiotic variables found in this study corroborated a previous study from lakes with similar characteristics. Ferrari (2010) attributed the low spatial heterogeneity to morphometric characteristics, like small area and shallow waters. It is known that differences among habitats affect the phytoplankton composition. However, when the micro-habitats are very similar, the phytoplankton communities also following this trend (Pereira, 2013).

The tropical Brazilian Northeast is known for its irregular rainfall patterns and long periods of drought that strongly influence the functioning of shallow lakes (Chellappa et al., 2009; Dantas et al., 2012). Environmental conditions in tropical lakes are influenced by rainfall events that modify the water volume and, consequently, the phytoplankton dynamics. Higher biomasses of algae result from the constant mixing of the water column by winds, stirring the sediment up and enabling re-alimentation, which could have enhanced the occurrence of cyanobacteria detected in this study (Borges et al., 2008; Cunha \& Calijuri, 2011; Dantas et al., 2012).

The highest rainfall (occurred in March) may have led to a slight instability in water column. However, this did not affect the abiotic variables, including phosphorus concentrations. Besides, the rainfall amount was enough to promote the increase in $\mathrm{N}$ group biomass. The $\mathrm{N}$ group was constituted by desmids, diatoms commonly found in oligo-mesotropic environments and tolerant to nutrient deficiency (Reynolds et al., 2002; Padisák et al., 2009).

The Canonical Correspondence Analysis showed that water temperature, orthophosphate, total phosphorus and $\mathrm{pH}$ had the greatest influence on functional groups dynamics. Other studies have attributed the predominance of those variables to the prolonged periods of drought (Cunha \& Calijuri, 2011). The most important variables along axis 1 (total phosphorus and orthophosphate) directly influenced X1, S1 and K groups, showing that their occurrence is associated to warm, shallow meso-trophic environments with well-mixed water columns (Reynolds et al., 2002).

The functional groups N, SN, and TD were associated to water temperatures and $\mathrm{pH}$ values (CCA), consistent with their occurrence in shallow warm waters moderately enriched and alkaline (Cunha \& Calijuri, 2011; Reynolds et al., 2002; Padisák et al., 2009). The $S 1$ group, predominant on the temporal scale, and the $\mathrm{SN}$ group are associated to high temperatures and able to coexist in environments with macrophytes, due to the shade provided (Araújo et al., 2009; Padisák et al., 2009).

The submerged macrophyte cover and the phytoplankton biomass remained temporally and spatially stable resulting in high spatial and temporal uniformity in the abiotic variables and functional groups. However, small seasonal fluctuations between functional groups was observed, as increase of the $\mathrm{N}$ group and reduction of the $\mathrm{SN}$ associated with the rainfall period. In conclusion, the ausence of significant differences in the composition and structure of functional groups (FGs) along the macrophyte cover confirm the tendency that in small and shallow lakes communities of limnetic and coastal zones tend to be similar.

\section{Acknowledgements}

To the Federal University of Paraiba and the Limnology Laboratory (UFPB/CCA) for all their support.

\section{References}

ALVARES, C.A., STAPE, J.L., SENTELHAS, P.C., GONÇALVES, J.L.M. and SPAROVEK, G. Köppen's climate classification map for Brazil. Meteorologische Zeitschrift, 2013, 22(6), 711-728. http://dx.doi.org/10.1127/0941-2948/2013/0507.

AMERICAN PUBLIC HEALTH ASSOCIATION APHA. Standard methods for the examination of water and wastewater. 21st ed. Washington: APHA, 2005.

ARAÚJO, G.J.M., PIRES, A.M.A., BARBOSA, J.E.L., SANTANA, R.M.C.S., SILVA, K.R.P.S. and DINIZ, C.R. Grupos funcionais e diversidade da comunidade fitoplânctonica do rio Taperoá, semiárido paraibano. In: Anais do $60^{\circ}$ Congresso Nacional de Botânica. Feira de Santana: Sociedade Brasileira de Botânica, 2009.

BORGES, P.A.F., TRAIN, S. and RODRIGUES, L.C. Estrutura do fitoplâncton em curto período de tempo, em um braço do reservatório de Rosana (Ribeirão do Corvo, Paraná, Brasil). Acta Scientiarum Biological Sciences, 2008, 30(1), 57-65.

CANFIELD JUNIOR, D.E., SHIREMAN, J.V., COLLE, D.E., HALLER, W.T., WATKINS II, C.E. and MACEINA, M.J. Prediction of Chlorophyll 
a Concentrations in Florida Lakes: Importance of Aquatic Macrophytes. Canadian Journal of Fisheries and Aquatic Sciences, 1984, 41(3), 497-501. http:// dx.doi.org/10.1139/f84-059.

CHELlAPPA, N.T., CHELLAPPA, T., CÂMARA, F.R.A., ROCHA, O. and CHELLAPPA, S. Impact of stress and disturbance factors on the phytoplankton communities in Northeastern Brazil reservoir. Limnologica, 2009, 39(4), 277-282. http://dx.doi. org/10.1016/j.limno.2009.06.006.

COLE, G. Textbook of limnology. 2nd ed. Saint Louis: The C.V. Mosby, 1994. 283 p.

COSTA, D.F. and DANTAS, E.W. Diversity of community in different urban aquatic ecosystems in metropolitan João Pessoa, state of Paraíba, Brazil. Acta Limnologica Brasiliensia, 2011, 23(4), 394-405. http://dx.doi.org/10.1590/S2179975X2012005000018.

CROSSETTI, L.O., BECKER, V., CARDOSO, L.S., RODRIGUES, L.R., COSTA, L.S. and MOTTA-MARQUES, D. Is phytoplankton functional classification a suitable tool to investigate spatial heterogeneity in a subtropical shallow lake? Limnologica, 2013, 43(3), 157-163. http://dx.doi. org/10.1016/j.limno.2012.08.010.

CUNHA, D.G.F. and CALIJURI, M.C. Variação sazonal dos grupos funcionais fitoplanctônicos em braços de um reservatório tropical de usos múltiplos no estado de São Paulo (Brasil). Acta Botanica Brasílica, 2011, 25(4), 822-831. http://dx.doi.org/10.1590/S010233062011000400009 .

DANTAS, Ê.W., BITTENCOURT-OLIVEIRA, M.C. and MOURA, A.N. Dynamics of phytoplankton associations in three reservoirs in Northeastern Brazil assessed using Reynolds' Theory. Limnologica, 2012, 42(1), 72-80. http://dx.doi.org/10.1016/j. limno.2011.09.002.

FERRARI, F. Estrutura e dinâmica da comunidade de algas planctônicas e perifíticas (com ênfase nas diatomáceas) em reservatórios oligotrófico e hipertrófico, Parque Estadual das Fontes do Ipiranga, São Paulo [Tese de Doutorado]. São Paulo: Instituto de Biociências de Rio Claro, Universidade Estadual Paulista, 2010.

FONSECA, B.M. and BICUDO, C.E.M. Phytoplankton seasonal and vertical variations in a tropical shallow reservoir with abundant macrophytes (Ninféias Pond, Brazil). Hydrobiologia, 2011, 665(1), 229-245. http:// dx.doi.org/10.1007/s10750-011-0626-3.

HILLEBRAND, H., DÜRSELEN, C.D., KIRSCHTEL, D., POLLINGHER, D. and ZOHARY, T. Bio-volume calculation for pelagic and benthic microalgae. Journal of Phycology, 1999, 35(2), 403-424. http://dx.doi.org/10.1046/j.15298817.1999.3520403.x.

HILT, S. and GROSS, E.M. Can allelopathically active submerged macrophytes stabilise clearwater states in shallow eutrophic lakes? Basic and Applied Ecology, 2008, 9(4), 422-432. http://dx.doi.org/10.1016/j. baae.2007.04.003.

HILT, S. Regime shifts between macrophytes and phytoplankton - concepts beyond shallow lakes, unravelling stabilizing mechanisms and practical consequences. Limnetica, 2015, 34(2), 467-480.

HILT, S., HENSCHKE, I., RÜCKER, J. and NIXDORF, B. Can submerged macrophytes influence turbidity and trophic state indeep lakes? Suggestions from a case study. Journal of Environmental Quality, 2010, 39(2), 725-733. http://dx.doi.org/10.2134/ jeq2009.0122. PMid:20176845.

IZAGUIRRE, I., ALLENDE, L., ESCARAY, R., BUSTINGORRY, J., PÉREZ, G. and TELL, G. Comparison of morpho-functional phytoplankton classifications in human- impacted shallow lakes with different stable states. Hidrobiologia, 2012, 698(1), 203-216. http://dx.doi.org/10.1007/s10750-0121069-1.

JENSEN, P., JEPPESEN, E., OLRIK, K. and KRISTENSEN, P. Impact of nutrients and physical factors on the shift from Cyanobacterial to Chlorophyte dominance in shallow Danish lakes. Canadian Journal of Fisheries and Aquatic Sciences, 1994, 51(8), 1692-1699. http://dx.doi.org/10.1139/ f94-170.

LUND, J.W.G., KIPLING, C. and LE CREN, E.D. The inverted microscope method of estimating algal numbers and the statistical basis of estimations by counting. Hydrobiologia, 1958, 11(2), 143-170. http://dx.doi.org/10.1007/BF00007865.

MATTEUCCI, S.D. and COLMA, A. Metodologia para el estudio de la vegetacion. Washington: The Genral Secretarial of the Organization of American States, 1982, 167 p. Série Biologia - Monografia, vol. 22.

PADISÁK, J., CROSSETTI, L.O. and NASELLIFLORES, E.L. Use and misuse in the application of the phytoplankton functional classification: a critical review with updates. Hydrobiologia, 2009, 621(1), 1-19. http://dx.doi. org/10.1007/s10750-008-9645-0.

PEREIRA, J.S. Estrutura e Dinâmica da comunidade fitoplanctônica no periodo de cinco anos em ambiente mesotrófico (Lago das Ninféias), Parque Estadual das Fontes do Ipiranga [Tese de Doutorado]. São Paulo: Universidade Estadual Paulista, Instituto de Biociências de Rio Claro, 2013, 94 p.

PINTO, P. T. and O'FARRELL, I. Regime shifts between free-floating plants and phytoplankton: a review. Hydrobiologia, 2014, 740(1), 13-24. http://dx.doi. org/10.1007/s10750-014-1943-0.

POOLE, H.H. and ATKINS, W.R.G. Photo-electric measurements of submarine illumination throughout the year. Journal of the Marine Biological Association 
of India, 1929, 16(1), 297-324. http://dx.doi. org/10.1017/S0025315400029829.

REYNOLDS, C.S., HUSZAR, V., KRUK, C., NASELLI-FLORES, L. and MELO, S. Towards a functional classification of the freshwater phytoplankton. Journal of Plankton Research, 2002, 24(5), 417-428. http://dx.doi.org/10.1093/ plankt/24.5.417.

ROS, J. Práctica de ecología. Barcelona: Omega, 1979.

SANCHÉZ, M.L., LAGOMARSINO, L., ALLENDE, L. and IZAGUIRRE, I. Changes in the phytoplankton structure in a Pampean shallow lake in the transition from a clear to a turbid regime. Hydrobiologia, 2015, 752(1), 65-76. http://dx.doi.org/10.1007/s10750014-2010-6.

SCHEFFER, M. and JEPPESEN, E. Regime shifts in shallow lakes. Ecosystems (New York, N.Y.), 2007, 10(1), 1-3. http://dx.doi.org/10.1007/s10021-0069002-y.
SCHEFFER, M., HOSPER, S.H., MEIJER, M.-L., MOSS, B. and JEPPESEN, E. Alternative equilibria in shallow lakes. Trends in Ecology \& Evolution, 1993, 8(8), 275-279. http://dx.doi.org/10.1016/01695347(93)90254-M. PMid:21236168.

SUN, J. and LIU, D. Geometric models for calculating cell bio-volume and surface area for phytoplankton. Journal of Plankton Research, 2003, 25(11), 1331 1346. http://dx.doi.org/10.1093/plankt/fbg096.

UTERMÖHL, H. Zur Vervoll kommnung der quantitativen phytoplankton-methodic. Mitteilungen Internationale Vereinigung für Theoretische und Angewandte Limnologie, 1958, 9, 1-38.

WETZEL, R.G. and LIKENS, G.E. Limnological analyses. Berlim: Springer, 2000, 429 p. http://dx.doi. org/10.1007/978-1-4757-3250-4.

Received: 07 December 2016 Accepted: 07 August 2017 